\title{
A THIRD REVOLUTION IN FAMILY DISPUTE RESOLUTION: ACCESSIBLE LEGAL PROFESSIONALISM
}

\author{
Noel Semple*
}

Innovation in family law firms can tangibly improve access to justice in Canada. This article develops that claim by drawing on empirical data and scholarship about Canadian family law. Part 1 explains how and why legal needs arising from the dissolution of intimate relationships are so difficult for the parties to meet. This Part draws on civil legal needs surveys, surveys with lawyers, and data from interviews with litigants. The focus shifts to family law firms (including sole practitioners) in Part 2, using new empirical data about the Canadian lawyers who do this work. Three promising opportunities to innovate for accessibility in family law practice are identified: (i) innovative fee structure; (ii) innovative service variety; and (iii) innovative division of labour. A "third revolution" in Canadian family law is proposed in Part 3. Our family law doctrine was revolutionized beginning in the 1960s, and family law alternative dispute resolution was similarly transfigured beginning in the 1980s. It is now time to foment a third revolution, in family law practice accessibility, to bring the benefits of family justice to all Canadians who need them.

L'innovation au sein des cabinets spécialisés en droit de la famille peut apporter des améliorations concrètes à l'accès à la justice au Canada. C'est ce que soutient l'auteur dans cet article, en se fondant sur des données et recherches empiriques sur le droit de la famille canadien. Dans la première partie, il explique comment naissent les besoins juridiques des parties en instance de séparation ou de divorce, et pourquoi il est si difficile de répondre à ces besoins. Cette partie est fondée sur des enquêtes portant sur les besoins juridiques en matière civile, sur des sondages menés auprès des avocats et sur des données découlant d'entrevues auprès des parties aux litiges. Dans la deuxième partie, l'accent est mis sur les cabinets spécialisés en droit de la famille (y compris les avocats qui travaillent seuls), et l'auteur s'inspire cette fois de nouvelles données empiriques au sujet des avocats canadiens qui exercent dans ce domaine. Des possibilités d'innovation susceptibles d'accroître l'accessibilité dans le domaine du droit de la famille sont relevées dans trois domaines : (i) la structure des honoraires; (ii) l'éventail de services; (iii) la répartition de la main-d'œuvre. Une " troisième révolution » en droit de la famille canadien est proposée dans cette même partie. Notre doctrine dans ce domaine a été révolutionnée à compter des années 1960, et le mode substitutif de résolution des différends en matière familiale a lui aussi été transfiguré à compter des années 1980. Le moment est maintenant venu de fomenter une troisième révolution, qui viserait cette fois-ci l'accessibilité de la pratique en

\footnotetext{
Noel Semple, Assistant Professor, Faculty of Law, University of Windsor, Canada, www.noelsemple.ca. The author was a member of the Editorial Board of the Windsor Yearbook of Access to Justice at the time when this article was submitted, and subsequently became Editor-in-Chief. All decisions pertaining to the peer review and acceptance of this article were made by the Guest Editors of this issue and by other members of the Yearbook Editorial board, without any input from the author.
} 
droit de la famille, afin de permettre à tous les Canadiens qui en ont besoin de bénéficier des services de justice en matière familiale.

When Canada's worst access-to-justice problems are listed, family law always makes the list. ${ }^{1}$ Although comprehensive legal remedies now exist for the dislocations and financial inequities caused by separation, people often struggle to obtain the benefit of those remedies. Recent empirical research makes this very clear. ${ }^{2}$ Today, workable solutions to enhance access to family justice are being developed by researchers and commentators. Public sector innovation - including in family courts, government ministries, law schools, and legal aid programs - has been the focus of much of this work. ${ }^{3}$ However, private sector, client-paid family law practice has not yet received the same level of attention in the scholarship. ${ }^{4}$

Innovation in family law firms can tangibly improve access to justice in Canada. The present article develops this claim by drawing on empirical data and scholarship about Canadian family law. The first part of the article explains how and why legal needs arising from the dissolution of intimate relationships are so difficult for people to meet. The discussion draws on civil legal needs surveys, surveys with lawyers, and data from interviews with litigants. The focus shifts to family law firms (including sole practitioners) in the second part of the article, using new empirical data about the Canadian lawyers who do this work. Three promising opportunities to innovate for accessibility in family law practice are identified: (1) innovative fee structure; (2) innovative service variety; and (3) innovative division of labour. A third revolution in Canadian family law is proposed in the third part of the article. Our family law doctrine was revolutionized beginning in the 1960s, and family law alternative dispute resolution was similarly transfigured beginning in the 1980s. It is now time to foment a third revolution in family law practice accessibility in order to bring the benefits of family justice to all Canadians who need them.

1 Action Committee on Access to Justice in Civil and Family Matters (ACAJCFM) Family Justice Working Group, Meaningful Change for Family Justice: Beyond Wise Words (Ottawa: ACAJCFM, 2013), online: <http://www.westcoastleaf.org/userfiles/file/FJWG\%20report\%20Meaningful\%20Change\%20Consultation\%20Jan\%202013.pdf> [ACAJCFM, Meaningful Change for Family Justice]; R Roy McMurtry et al, Listening to Ontarians: Report of the Ontario Civil Legal Needs Project (Toronto: Ontario Civil Legal Needs Project Steering Committee, 2010), online: Law Society of Upper Canada (LSUC) <http://www.lsuc.on.ca/media/may3110_oclnreport_final.pdf>; Carol Rogerson, "Shaping Substantive Law to Promote Access to Justice: Canada's Use of Child and Spousal Support Guidelines" in John Eekelaar, Mavis Maclean \& Benoit Bastard, eds, Delivering Family Justice in the 21st Century (Oxford: Hart Publishing, 2015) 51; Noel Semple, "The Cost of Seeking Civil Justice in Canada" (2015) 93 Can Bar Rev 639 at 669, online: $<$ http://ssrn.com/abstract=2616749> [Semple, "Cost of Seeking Civil Justice"].

2 Julie Macfarlane, The National Self-Represented Litigants Project: Identifying and Meeting the Needs of SelfRepresented Litigants (Kingsville, ON: Representing Yourself in a Legal Process (RYLP), 2013), online: < https://representingyourselfcanada.com/wp-content/uploads/2016/09/srlreportfinal.pdf > [Macfarlane, National SelfRepresented Litigants Project].

3 ACAJCFM, Access to Civil and Family Justice: A Roadmap for Change (Toronto: Canadian Forum on Civil Justice (CFCJ), 2013), online: $<$ http://www.cfcj-fcjc.org/sites/default/files/docs/2013/AC_Report_English_Final.pdf $>$ [ACAJCFM, Access to Civil \& Family Justice]; Law Commission of Ontario (LCÖ), Increasing Access to Family Justice through Comprehensive Entry Points and Inclusivity (Toronto: LCO, 2013) online: <http://www.lcocdo.org/en/our-current-projects/family-law-reform/increasing-access-to-family-justice-through-comprehensive-entrypoints-and-inclusivity-final-report-february-2013/> ; Noel Semple \& Nicholas Bala, Reforming the Family Justice System: An Evidence-Based Approach (Report commissioned by the Association of Family and Conciliation Courts (AFCC), Ontario Chapter) (Toronto: AFCC Ontario Chapter, 2013), online: Social Science Research Network $<$ http://ssrn.com/abstract=2366934>; Advocates' Society, Family Justice Reform Project (Toronto: Advocates' Society (Ontario), 2014).

4 However, the Canadian Bar Association's (CBA) Futures Initiative has focused on innovation in Canadian legal practice generally. See CBA Legal Futures Initiative, Futures: Transforming the Delivery of Legal Services in Canada (Ottawa: CBA, 2014) at 31, online: <http://www.cbafutures.org/cba/media/mediafiles/PDF/Reports/Futures-Final-eng.pdf $>$. 


\section{ACCESS TO FAMILY JUSTICE}

\section{A. Needs and Remedies}

What exactly is included in family law? All legal needs that arise from the dissolution of intimate relationships between cohabiting adults are family law needs for the purposes of this article. ${ }^{5}$ Canadian law includes three broad categories of remedy for family law needs:

1. Financial family law, including child support, spousal support, matrimonial property division, and matrimonial home remedies. These remedies are meant to provide equitable division of the fruits of the relationship and of the costs of its dissolution.

2. Child custody and access law, which allocates post-separation parenting rights and responsibilities with the stated goal of maximizing the best interests of the child(ren).

3. Legal measures to prevent domestic violence, borrowed from criminal law, are also now central to family law.

These remedies are found in the federal Divorce Act, in provincial legislation, and in a deep body of case law. ${ }^{6}$ In addition to divorce, the intimate relationships in question include long-term non-marital relationships, whose parties are treated like married people for some (although not all) purposes under Canadian family law. Members of same sex and opposite sex relationships are now treated equally under separation-related family law in this country. ${ }^{7}$

\section{B. Family Law: An Access-to-Justice Quagmire}

Several factors make family law a significant access-to-justice problem. First, large numbers of people are involved. Four in every ten Canadian marriages are expected to end in divorce. ${ }^{8}$ Unmarried cohabitants are even more likely to separate before death does them part. ${ }^{9}$ Although some separations occur without any conflict or legal needs, many do not. Within a three-year period, 1,216,497 Canadians (5.1 percent of the adult population) reported experiencing a family law problem that was "serious ... and not easy to fix" according to the 2014 National Legal Problems Survey. ${ }^{10}$ What factors distinguish family law needs from other legal needs and make this area an access-to-justice quagmire? Family law needs are challenging, first, for the same reasons that other "personal plight" legal needs are challenging. However, they are in some ways more legally challenging than many other personal plight needs, for reasons considered in the next section of this article.

5 Thus, child protection cases are not part of the focus here.

6 Another important doctrinal source, which has been incorporated through jurisprudence, is Carol Rogerson \& Rollie Thompson, Spousal Support Advisory Guidelines (final version) (Ottawa: Department of Justice (Canada), 2008), online: < www.canada.justice.gc.ca/eng/fl-df/spousal-epoux/ssag-ldfpae.html >. Divorce Act, RSC 1985, c 3.

7 Civil Marriage Act, SC 2005, c 33; Halpern v Toronto (City) (2003), 36 RFL (5th) 127 (Ont CA) and subsequent jurisprudence.

8 Mary Bess Kelly, Divorce Cases in Civil Court, 2010/2011 (Ottawa: Juristat: Canadian Centre for Justice Statistics, 2012).

9 Anne-Marie Ambert, Cohabitation and Marriage: How Are They Related? (Ottawa: Vanier Institute for the Family, 2005).

10 Trevor CW Farrow et al, Everyday Legal Problems and the Cost of Justice in Canada: Overview Report (Toronto: CFCJ, 2016) at 7, online: <http://www.cfcjfcjc.org/sites/default/files//Everyday\%20Legal\%20Problems $\% 20$ and $\% 20$ the $\% 20$ Cost\%20of\%20Justice\%20in\%20Canada\%20-\%20Overview\%20Report.pdf>; CFCJ, Everyday Legal Problems and the Cost of Justice in Canada: Survey (Toronto: CFCJ, 2016) at 2, online: <http://www.cfcjfcjc.org/sites/default/files//Everyday\%20Legal\%20Problems \%20and $\% 20$ the $\% 20$ Cost $\% 20$ of $\% 20 J u s t i c e \% 20$ in $\% 20$ Canada $\% 20-\% 20$ Survey.pdf $>$. 


\section{Family Law as Personal Plight}

The "personal plight" sector includes all legal needs that (1) are experienced by individuals (as opposed to corporations or state bodies) and (2) arise from disputes as opposed to transactions, regulatory compliance efforts, or planning. ${ }^{11}$ Criminal defence law, employee-side employee law, and plaintiff-side personal injury law are all examples of personal plight. Other individual legal needs that frequently go unmet - for example, lacking a will or lacking appropriate legal advice on signing a mortgage ${ }^{12}-$ are $^{2}$ considered "personal business" needs as opposed to personal plight because they do not arise from disputes. Access to justice is problematic throughout the personal plight sector for several reasons.

\section{Legal Inexperience in Personal Plight}

Unlike corporations, individuals are usually inexperienced "one-shotters," 13 who have never experienced their type of legal need before. ${ }^{14}$ Legal inexperience increases the psychological costs of the legal need for the person experiencing it. ${ }^{15}$ Those who are novices in a certain type of legal forum presumably also have more difficulty reaching an acceptable resolution without professional help, compared to those who have been through something similar before.

\section{Underlying Crisis in Personal Plight}

Second, personal plight needs are usually caused by an underlying life crisis. Car crashes, arrests, and marital breakdowns are stressful experiences even if no legal needs arise from them. ${ }^{16}$ The legal needs that typically do arise from them must be dealt with at the same time that the person deals with the underlying crisis that gave rise to the need. ${ }^{17}$ This compounds the challenge of addressing the legal need in a way that is not experienced by those whose legal needs do not arise from crisis or conflict. In the case of family law, the emotional and financial crisis of separation is often compounded by anxiety for the future and domestic violence (which is present in the majority of intimate relationships that end in voluntary separation). ${ }^{18}$

\section{Legal Fee Affordability in Personal Plight}

Retaining professional legal help is the obvious way to reduce the temporal and emotional costs of addressing a personal plight legal need. ${ }^{19}$ However, legal fees for personal plight needs, as opposed to other legal needs, tend to be difficult to afford, even in cases where the fees are modest in absolute terms.

11 John P Heinz \& Edward O Laumann, Chicago Lawyers: The Social Structure of the Bar (New York: Russell Sage Foundation \& American Bar Foundation, 1982); John P Heinz et al., Urban Lawyers: The New Social Structure of the Bar (Chicago: University of Chicago Press, 2005); Noel Semple, Accessibility, Quality, and Profitability for Personal Plight Law Firms: Hitting the Sweet Spot (Ottawa: 2017) online: Canadian Bar Association $<$ www.cba.org/PersonalPlight $>$ (last accessed: 24 September 2017) [Semple, Sweet Spot].

12 Gillian K Hadfield, "Higher Demand, Lower Supply? A Comparative Assessment of the Legal Landscape for Ordinary Americans" (2010) 37 Fordham Urban LJ 129 at 132, online: <http://works.bepress.com/ghadfield/31>.

13 Marc Galanter, "Why the "Haves" Come Out Ahead: Speculations on the Limits of Legal Change" (1974) 9 Law \& Society Rev 59, online: <jan.ucc.nau.edu/ phelps/Galanter\%201974.pdf>.

14 ACAJCFM, Meaningful Change for Family Justice, supra note 1 at 16-17.

15 Semple, "Cost of Seeking Civil Justice," supra note 1.

16 ACAJCFM, Meaningful Change for Family Justice, supra note 1 at 14-15.

17 Semple, "Cost of Seeking Civil Justice," supra note 1 at 665.

18 Jessica Pearson, "Mediating When Domestic Violence Is a Factor: Policies and Practices in Court-Based Divorce Mediation Programs" (1997) 14 Mediation Quarterly 319 at 320; Desmond Ellis, "Divorce and the Family Court: What Can Be Done about Domestic Violence?" (2008) 46 Family Court Review 531 at 531.

19 Semple, "Cost of Seeking Civil Justice," supra note 1. 
Unlike a corporation's legal fees, personal plight legal fees cannot be deducted from the client's income for tax purposes. In Canada, legal services are now fully subject to sales tax (goods and service tax / harmonized sales tax), and, in some parts of the country, they are taxed more onerously than other goods and services. ${ }^{20}$ Executives of a corporation pay its legal fees from shareholders' pockets; a personal plight client must pay from her own pocket. Borrowing to pay a personal plight legal fee is much more difficult than it would be for a lawyer's fee on transferring a home because there is typically no large asset available to secure a loan. Finally, because personal plight legal needs are so often unanticipated, they cannot be planned for, or saved up for, in advance.

\section{Family Law: Compared to Other Personal Plight}

Access to family law justice also faces unique impediments that do not apply to other personal plight legal needs. This section will compare family law with other personal plight legal needs, with a view to explaining why family law is an access-to-justice quagmire.

\section{Prevalence and Severity of Personal Plight Needs: How Does Family Law Compare?}

Data from civil legal needs surveys paint a somewhat complex picture on this point. Family law problems were by far the most frequently mentioned legal problems for which people wished to have legal help, according to the 2009 Ontario Civil Legal Needs [OCLN] survey. ${ }^{21}$ When asked the question: "for what types of problems or issues did you seek assistance?" the OCLN respondents mentioned family law problems more than twice as often as any other type of problem. "Family relationship problems" were identified by 12.1 percent of the respondents ( 30 percent of those who mentioned any type of civil legal problem) compared to 5.6 percent or less for all other problem types. ${ }^{23}$

However, a very different finding came from the National Legal Problems Survey [NLPS] conducted in 2014, which had a larger and a more comprehensive sample of adult Canadians than the OCLN. ${ }^{24}$ According to this data, consumer, debt, and employment problems are significantly more common than family law problems in the lives of Canadians. ${ }^{25}$ Most other civil legal needs surveys in Canada and abroad have reached similar conclusions: family law needs are prevalent but not in the top three categories. ${ }^{26}$

20 Canadian Bar Association, British Coumbia Branch, "Double Taxation on Legal Fees and Other Professional Services," Resolution 13-07-A (August 17, 2013).

21 McMurtry et al., supra note 1; Environics Group, Civil Legal Needs of Lower and Middle-Income Ontarians: Quantitative Research (Toronto: Environics Research Group, 2009) at 1-2, online: LSUC

$<$ http://www.1suc.on.ca/media/may3110_oclnfocusgroupsresearchreport.pdf $>$. Only Ontarians with household income less than $\$ 75,000$ were surveyed for the Ontario Civil Legal Needs (OCLN) survey.

22 Environics Group, supra note 21 at 16; Jamie Baxter, Michael Trebilcock \& Albert Yoon, "The Ontario Civil Legal Needs Project: A Comparative Analysis of the 2009 Survey Data" in Michael Trebilcock, Anthony Duggan \& Lorne Sossin, eds, Middle Income Access to Justice (Toronto: University of Toronto Press, 2012) 55.

23 Environics Group, supra note 21 at 16.

24 The National Legal Problems Survey (NLPS) surveyed 3,263 adult Canadians from across the country and, unlike the OCLN, was not limited by household income. David Northrup et al., Design and Conduct of the Cost of Justice Survey (Toronto: CFCJ, 2016) online: <http://www.cfcjfcjc.org/sites/default/files//Design\%20and\%20Conduct\%20of\%20the$\% 20$ Cost $\% 20$ of $\% 20 J u s t i c e \% 20$ Survey.pdf $>$

25 Respectively, these problem types were reported by $22.6 \%, 20.8 \%$, and $16.4 \%$ of adult Canadians asked to think about serious/difficult to fix problems arising in the previous three years. Problems with neighbours were reported by $9.8 \%$ and discrimination problems were reported by 5.3\%. Farrow et al, supra note 10 at 8 .

26 Baxter, Trebilcock \& Yoon, supra note 22; Ab Currie, The Legal Problems of Everyday Life: The Nature, Extent and Consequences of Justiciable Problems Experienced by Canadians (Ottawa: Department of Justice Canada, 2007) at 15, online: Department of Justice Canada <http://www.justice.gc.ca/eng/rp-pr/csj-sjc/jsp-sjp/rr07_la1-rr07_aj1/rr07_la1.pdf> [Currie, Legal Problems]. 
Jamie Baxter, Michael Trebilcock, and Albert Yoon offer a convincing explanation for the OCLN's outlier placement of family law problems in the top rank for problem prevalence. The OCLN survey asked respondents an open-ended question about the legal needs they had experienced, whereas the NLPS and other civil legal needs surveys prompted respondents with a series of queries about various problem types. Absent such a prompt, respondents are less likely to recognize consumer, debt, and employment problems as being "legal" in nature. ${ }^{27}$ This reflects limited legal consciousness, which is defined by Lesley Jacobs as "an individual's knowledge or awareness of the law and its potential for resolving disputes and affecting social change." 28

Legal consciousness is high for family law needs relative to some other personal plight legal needs (for example, consumer and debt problems). ${ }^{29}$ The financial, child-related, and domestic violence-related needs arising from separation are broadly recognized by the people who experience them to have legal dimensions and potential legal solutions and to merit seeking legal remedies. ${ }^{30}$ Separation is also more heavily legalized by our system than are some other major life transitions (for example, termination of employment). For example, even completely uncontested divorce still requires a court order in this country. ${ }^{31}$ In short, separation is a major source of legal needs not only because it is common (even if not in the top three) but also because relatively high legal consciousness and relatively heavy legalization lead a relatively large proportion of those with this sort of problem to seek out legal remedies.

\section{Family Law Needs in Court}

Thus, it is not surprising that a full third of all of the non-criminal cases heard in Canadian courts are family law cases, even though other civil legal problems arise more frequently in people's lives. ${ }^{32}$ There are pervasive unmet needs in our family law courts. With 50-70 percent of family litigants selfrepresented, only small claims courts and certain tribunals have fewer lawyers per litigant than our family courts do. ${ }^{33}$ In family court as elsewhere, financial reasons are by far the most common reasons cited by self-represented litigants [SRLs] for why they are self-represented. ${ }^{34}$ This obviously reflects a mismatch between SRLs' financial resources and the price of legal services. ${ }^{35}$ However, in some cases, it also reflects a lack of sufficient perceived value in the legal services available. ${ }^{36}$ As Julie MacFarlane explains,

27 Baxter, Trebilcock \& Yoon, supra note 22 at 77.

28 Lesley Jacobs, Mapping the Legal Consciousness of First Nations Voters: Understanding Voting Rights Mobilization (Ottawa: Elections Canada, 2009) at 10, n 10, online: Elections Canada $<$ http://www.elections.ca/med/eve/A-

PRC/vot_rights_e.pdf $>$.

29 Noel Semple \& Carol Rogerson, “Access to Family Justice: Insights and Options“ in Trebilcock, Duggan \& Sossin, supra note 22, 413 at 419.

30 Matthew Dylag, The Resolution of Legal Problems in Ontario, CFCJ working paper (2016), online: <http://www.cfcjfcjc.org/sites/default/files//The\%20Resolution\%20of\%20Legal\%20Problems\%20in\%20Ontario.pdf $>$.

31 Divorce Act, supra note 6 at s 8(1). See also Currie, Legal Problems, supra note 26 at 5-6.

32 Kelly, supra note 8 at Text Box 2. This statistic is based on "seven reporting provinces and territories (Nova Scotia, Ontario, Alberta, British Columbia, Yukon, Northwest Territories and Nunavut, representing 66\% of Canada's population)." It includes uncontested divorces.

33 Department of Justice (Canada), The Unified Family Court Summative Evaluation Final Report (Ottawa: Department of Justice, 2009).

34 Macfarlane, National Self-Represented Litigants Project, supra note 2 at 32; Rachel Birnbaum, Nicholas Bala \& Lorne Bertrand, "The Rise of Self-Representation in Canada's Family Courts: The Complex Picture Revealed in Surveys of Judges, Lawyers \& Litigants“" (2013) 91 Can Bar Rev 67 at 76.

35 See section II.A below.

36 Mary Eberts, "'Lawyers Feed the Hungry:' Access to Justice, the Rule of Law, and the Private Practice of Law" (2013) 76 Sask L Rev 115 at 125. 
many SRLS "do not accept that the work performed by legal counsel should be as costly as it is." 37 Moreover, after procedural reform and shifts in public perception, representing oneself is now perceived by many as a viable, albeit not ideal, option. Some SRLs are confident in their ability to represent themselves, ${ }^{38}$ although this confidence often dissipates as a proceeding grinds on. ${ }^{39}$ Clearly, family court is a deep well of unmet legal needs.

\section{Family Law Needs Out of Court}

Court appearances and contested adjudications are rare; most separating people reach consensual financial and child-care arrangements. ${ }^{40}$ However, unmet legal needs are also rife in these non-litigated separations. Even if they know that the law offers a remedy, many people do not know the details and therefore walk away from their entitlements. Others have a good idea of their entitlements under family law but abandon them because they cannot afford the financial, temporal, and emotional costs of pursuing those entitlements. ${ }^{41}$ Whether inside or outside of court, competent legal assistance is of great help to people seeking access to family justice. The NLPS found that 81 percent of people who had obtained legal advice for a civil legal need were satisfied with that advice. ${ }^{42}$ Why is such assistance so hard for separating people to obtain? The next sections will suggest that financial characteristics of family law cases, combined with adverse public policy decisions, help put family law firms out of reach for most Canadians.

\section{No Pot of Gold at the End of the Rainbow}

In some personal plight cases, there is a "pot of gold" expected at the end of the dispute "rainbow." Many estate litigants, for example, can reasonably expect to receive a bequest or settlement from the estate being contested. The anticipated "pot of gold" may allow the firm to defer billing until the end of the case. ${ }^{43}$ Even if not, the bequest is often a windfall that improves the overall financial position of the litigant and improves his or her ability to absorb the legal fees required to secure it. A personal injury plaintiff has no windfall in the offing; at best, she will receive money to compensate her for what she has lost. However, in most significant personal injury cases, it is more or less certain that something will eventually be paid by the defendant insurer after settlement or judgment. This anticipated "pot of gold" allows personal injury firms to accept payment on a contingency basis, which is significantly more affordable to the client than the upfront cash retainers typically required by family law firms. ${ }^{44}$

Divorce, by contrast, is a financial blow even if it involves no legal fees. In most cases, the net family income that previously supported one household will be required to support two households going forward. There is typically no pot of gold at the end of the rainbow. The legal fees compound the existing

37 Macfarlane, National Self-Represented Litigants Project, supra note 2 at 40. See also Birnbaum, Bala \& Bertrand, supra note 34 at 76: "For many middle income individuals ... the decision not to retain a lawyer is often at least in part based on their assessment that, given their income and asset level, the value of having a lawyer would not justify the cost. In other words, they have absolute ability to pay, but given the costs of legal services and their perceptions of its limited value for them, they have chosen to spend their money on other priorities." Birnbaum, Bala \& Bertrand, supra note 34 at 78.

39 Macfarlane, National Self-Represented Litigants Project, supra note 2 at 50-55.

40 "In 2010/2011, the majority of active divorce cases $(80 \%)$ in the reporting jurisdictions were uncontested, with the remaining $20 \%$ being contested or disputed cases." Kelly, supra note 8.

41 Semple, "Cost of Seeking Civil Justice," supra note 1; Paul Millar, The Best Interests of Children: An Evidence-Based Approach (Toronto: University of Toronto Press, 2009) at 118-119.

42 Farrow et al, supra note 10 at 10. See also Ipsos Reid, “Albertans Satisfied with Their Lawyers" (18 May 2010 ).

43 Even if the client must pay a large cash retainer and time-based bills, these are easier to manage through short-term borrowing if the client knows that a bequest is in the offing.

44 Semple, Sweet Spot, supra note 11, Chapter 2. 
financial blow suffered by the separating parties, especially if the family law firm requires a large cash retainer upfront. ${ }^{45}$

\section{Lack of Legal Aid}

Public policy decisions have also made access to family justice difficult compared to other personal plight needs. Legal aid funding generally deprioritizes family law relative to other personal plight legal needs such as criminal law. ${ }^{46}$ In a national survey, Canadian family lawyers reported that $81.6 \%$ of their clients had not received any legal aid funding. ${ }^{47}$ The certificates that entitle one to a full-service family lawyer paid for by the state are especially difficult to come by in most parts of the country. This reflects Supreme Court of Canada decisions that mandate legal aid for cases imperilling individuals' interests under the Canadian Charter of Rights and Freedoms (for example, cases threatening incarceration or state apprehension of one's children $)^{48}$ but not for separation-related family law cases, which generally do not involve the state or Charter interests. ${ }^{49}$

\section{Lack of Paralegal Service}

Independent paralegals are trained and regulated legal experts. Although good data is not available on this point, there is a widespread perception that licensed paralegals typically charge significantly less than lawyers do. ${ }^{50}$ Paralegals may offer a relatively affordable option for some personal plight legal needs for example, those arising from housing problems or minor criminal charges. However, independent paralegals are forbidden to offer family law services in most provinces. ${ }^{51}$ Those who try to do so can be prosecuted for the "unauthorized practice of law," whether or not there is any deficiency in the services

45 See section II.A below.

46 Michael Trebilcock, Report of the Legal Aid Review (Toronto: Ministry of the Attorney General (Ontario), 2008) at 7576, online: $<$ http://www.attorneygeneral.jus.gov.on.ca/english/about/pubs/trebilcock/>

47 Lorne D. Bertrand et al., The Practice of Family Law in Canada: Results from a Survey of Participants at the 2016 National Family Law Program (Calgary: Canadian Research Institute for Law and the Family, 2016) online: CRILF $<$ http://www.crilf.ca/Documents/RSD_2016_NFLP_Survey_of_Family_Court_EN.PDF $>$ (last accessed: 24 August 2017).

48 New Brunswick (Minister of Health \& Community Services) $v G(J)$, [1999] 3 SCR 46, [1999] SCJ No 47; $R v$ Rowbotham, 1988 CanLII 147 (ON CA). Canadian Charter of Rights and Freedoms, Part 1 of the Constitution Act, 1982, being Schedule B to the Canada Act 1982 (UK), 1982, c 11.

49 British Columbia (Attorney General) v Christie, [2007] 1 SCR 873, 2007 SCC 21; Ab Currie, The State of Civil Legal Aid in Canada: By the Numbers in 2011-2012 (Toronto: CFCJ, 2013); Erika Heinrich, Canadian Jurisprudence Regarding the Right to Legal Aid (Vancouver: Lawyers' Rights Watch Canada, 2013), online: LRWC < $<$ http://www.lrwc.org/canadian-jurisprudence-regarding-the-right-to-legal-aid-report/>. However, family law legal aid funding was recently increased in Ontario, and litigants are more likely to have access to duty counsel or other limitedscope assistance as opposed to traditional certificates.

50 Marshall Yarmus, "Yarmus: Ontario's Crisis in Family Courts," Ottawa Citizen (27 July 2015), online: $<\mathrm{http}$ //ottawacitizen.com/news/national/yarmus-ontarios-crisis-in-family-courts>; Macfarlane, National SelfRepresented Litigants Project, supra note 2; Julie Macfarlane, "Ontario Family Legal Services Review Offers Opportunity for Legal Profession to Show the Public It Is Listening - and Cares" (National Self-Represented Litigants Project Blog (16 May 2016), online: < https://representingyourselfcanada.com/ontario-family-legal-services-reviewoffers-opportunity-for-legal-profession-to-show-the-public-it-is-listening-and-cares/ $>$. Lower paralegal prices would also make economic sense, given the lower barriers to entry to this profession and the fact that there are fewer types of client competing for paralegal services.

51 Noel Semple, Legal Services Regulation at the Crossroads: Justitia's Legions (Cheltenham, UK: Edward Elgar, 2015) at 49-50 [Semple, Legal Services Regulation]; Noel Semple, "The Three Routes to Justice for All," Lawyers Weekly (30 October 2015). 
offered. ${ }^{52}$ In Ontario, family law is excluded from the scope of practice for licensed paralegals, ${ }^{53}$ although the Family Legal Services Review has recommended amendments to this rule. ${ }^{54}$ In other parts of the country, such as British Columbia, there are no independent paralegals; they must be supervised by lawyers. Alberta is somewhat more tolerant of independent paralegals offering advice or coaching in family law, although they may not appear in court. ${ }^{55}$

Canadian family law remains an access-to-justice quagmire. This is not only because these are personal plight legal needs but also because of financial factors and public policy decisions that distinguish family law needs from other types of personal plight legal needs. Despite substantial research and media focus in recent years, there is no evidence that access to family justice is tangibly improving in Canada. How can we dig our way out of this quagmire?

\section{CANADA'S FAMILY LAW FIRMS: INNOVATING FOR ACCESSIBILITY?}

One obvious place to look for access-enhancing innovation is the public justice "system," including courts and justice ministries as well as quasi-public entities such as legal aid commissions and law schools. ${ }^{56}$ Reformers and researchers have focused their energies here. However, the premise of this article is that Canada's family law firms (including sole practitioners) also have an essential role to play in the pursuit of access to justice. Even if the public sector family justice system were to be perfected, the average person involved in contested divorce or separation would still want a trusted, expert ally. More importantly, litigation should only ever be a last resort for separating people, given the enormous monetary, temporal, and emotional costs that it imposes. ${ }^{57}$ Job number one for good family law professionals is not representing clients in court; job number one is keeping separating people out of family court by securing their legal rights through settlement negotiation and other forms of alternative dispute resolution. ${ }^{58}$ Innovation that lets family law firms provide these benefits to more separating Canadians is urgently needed.

A solid empirical understanding of Canada's family law firms and their approach to delivering services can help identify plausible access-enhancing innovations. To this end, this section will draw on two previously unreported data sources. The first source is aggregate data collected from Ontario lawyers'

52 Joan Brockman, "Money for Nothing, Advice for Free: The Law Society of British Columbia's Enforcement Actions against the Unauthorized Practice of Law" (2010) 29 Windsor Rev of Legal \& Social Issues 1; Semple, Legal Services Regulation, supra note 49 at $47-48$.

53 LSUC, By-Law 4: Licensing (1 May 2007; most recently amended 19 October 2015).

54 Annemarie E. Bonkalo, Report of the Family Legal Services Review (Toronto: Ministry of the Attorney General (Ontario), 2016) online: MAG <https://www.attorneygeneral.jus.gov.on.ca/english/about/pubs/family_legal_services_review/> (last accessed: 24 August 2017)

55 Law Society of Alberta, Law Society of Manitoba \& Law Society of Saskatchewan, Innovating Regulation (Edmonton, Winnipeg, \& Regina: Law Society of Alberta, Law Society of Manitoba \& Law Society of Saskatchewan, 2015) online: $<$ https://www.lawsociety.sk.ca/media/127107/INNOVATINGREGULATION.pdf>.

56 Arguably, these entities currently lack the coordination that the word "system" connotes. CBA A2J Committee, Reaching Equal Justice: An Invitation to Envision and Act (Ottawa: CBA, 2013) at 49, online:

$<$ http://www.cba.org/cba/equaljustice/secure_pdf/Equal-Justice-Report-eng.pdf $>$; ACAJCFM, Access to Civil and Family Justice, supra note 3 at 7.

57 Semple, "Cost of Seeking Civil Justice," supra note 1.

58 Nicholas Bala, "Reforming Family Dispute Resolution In Ontario: Systemic Changes \& Cultural Shifts" in Michael Trebilcock, Anthony Duggan \& Lorne Sossin eds., Middle Income Access to Justice (Toronto: University of Toronto Press, 2012) at 274; Julie Macfarlane, The New Lawyer: How Settlement Is Transforming the Practice of Law (Vancouver: UBC Press, 2008). 
2014 annual reports, provided to the author by the Law Society of Upper Canada. ${ }^{59}$ The second source is the author's interviews with nine practising family lawyers, conducted as part of a larger program of interviews with various personal plight practitioners. ${ }^{60}$

As a preliminary matter, it is worth noting that family law is one of the largest legal practice niches. In total, 17 percent of all Ontario licensees, 4,820 individuals in total, indicated that they provided some family law services in 2014. Family lawyers outnumber those in niches that may be better known such as criminal lawyers (who number 3,701 in Ontario). Among the twenty practice niches recorded in the Law Society of Upper Canada annual report data, "family/matrimonial law" ranked fifth. ${ }^{61}$ Among all Ontario lawyers (including those who did no family law work), the average practitioner spent 8.82 percent of his or her working hours doing family law work.

Apart from traditional, time-billed legal practice, how can these legal professionals help dig us out of the access-to-family justice quagmire? Pro bono service is one straightforward option. Among the 4,820 Ontario lawyers who did any family law work in 2014, almost half (48.9 percent) reported doing some pro bono work. ${ }^{62}$ Ronit Dinovitzer's 2012 survey of new Canadian lawyers (in all practice areas) found that they did an average of forty-five hours per year. ${ }^{63}$ "Low bono" work is perhaps more common than pure pro bono in family law, although the Law Society of Upper Canada data does not track it. Low bono means reducing the hourly rate, offering more flexible payment terms, or discounting the final bill based on the client's modest means. ${ }^{64}$ Accepting family law legal aid certificates, which pay much less than market rates, ${ }^{65}$ is effectively low bono work for those family lawyers who could fill their calendars with clients paying higher rates. Altruistic voluntarism is commendable and valuable. However, the accessibility-enhancing innovations that are most likely to be widely adopted by family law firms are those that maintain or even improve firm profitability. Thus, it is upon these innovations that the remainder of this section will focus.

59 The author is grateful to the LSUC and, in particular, to Allison Cheron for generously providing this data. This research was authorized by University of Windsor Research Ethics Board Certificate no 32411, granted 19 June 2015 . No identifying information was provided to the author.

60 University of Windsor Research Ethics Board Certificate no 31927, granted 25 February 2015. For further findings from this research, and a comprehensive account of the methodology, see Semple, Sweet Spot, supra note 11.

61 The twenty practice areas on the form were: Aboriginal law; alternative dispute resolution/mediation services; administrative law; bankruptcy and insolvency law; civil litigation - plaintiff; civil litigation - defendant; construction law; corporate/commercial law; criminal/quasi criminal law; employment/labour law; environmental law; family/matrimonial law; franchise law; immigration law; intellectual property law; real estate law; securities law; tax law, wills, estates, trusts law; workplace safety and insurance law.

62 The data source does not indicate how much pro bono work they did nor does it indicate whether the pro bono work was for family law clients as opposed to other types of clients.

63 Ronit Dinovitzer, Law and Beyond: A National Study of Canadian Law Graduates (Toronto: University of Toronto Press, 2015) at 26.

64 Anna Lund \& Andrew Pilliar, What Do Lawyers Do? Examining the Types of Pro Bono, Low Bono and Voluntary Work Provided by British Columbia Lawyers (Vancouver: Law Foundation of British Columbia, 2014); Luz E Herrera, "Rethinking Private Attorney Involvement through a 'Low Bono“ Lens" (2009) 43 Loyola LA L Rev 1.

65 For civil matters, Legal Aid Ontario rates range between $\$ 81.44$ and $\$ 136.43$ per hour depending on seniority (as of October 2017). Legal Aid Ontario, "Information for Lawyers: Tariff \& Billing" online: LAO $<$ http://legalaid.on.ca/en/info/tariff_billing.asp $>$. The average market rate for family law services in Canada is approximately \$300. Semple, “Cost of Seeking Civil Justice," supra note 1 at 650-653. 


\section{A. Innovation in Price Structure}

Unaffordability is the most important reason why separating people go without the family law services that they need and want. ${ }^{66}$ According to the 2015 Going Rate survey conducted by Canadian Lawyer magazine, the average legal fee for representation in a contested divorce is $\$ 13,638$. Among those cases requiring a trial of "up to 5 days," the average reported figure was $\$ 35,950 .{ }^{67}$ A Toronto family lawyer explained the effect of legal fees on accessibility in her practice:

$[\mathrm{U}]$ nless someone's a high income earner they can't afford legal fees ... Anyone below $\$ 50,000$ per year or something like that, it's almost impossible to afford legal fees. I mean they're going to be paying child support, probably spousal support, probably their mortgage ... so getting legal fees to stretch in a situation like that, it's just not going to happen. ${ }^{68}$

Thus, Canadians who are able to afford family legal services tend to be relatively affluent. In one survey, $57 \%$ of Canadian family lawyers reported that their average client has an annual income in excess of $\$ 70,000 .^{69}$

In addition to the absolute prices being charged, two price structure factors further undermine the affordability of family law firms. First, time-based billing, which is standard practice for Canadian family law firms, requires clients to accept significant uncertainty about what the final price will be. ${ }^{70}$ Second, upfront cash retainer requirements, whereby the client must produce a four- or five-digit sum before any services are provided, are a major affordability impediment even for those who would be able to pay the full bill if given more time.

Exploring alternatives to the billable hour is an excellent opportunity to innovate for accessibility. ${ }^{71}$ Under flat fee billing, a fixed amount is charged to either (1) provide a specific family law service (for example, a consultation or document review) or (2) represent the client up to a specific milestone in the litigation (for example, mediation). Flat fee family law services are increasingly common in overseas jurisdictions. In England and Wales, 46 percent of family law firm clients who paid for their services did so through a flat fee, compared to only 28 percent who paid by the hour. ${ }^{72}$ Survey research in England and Wales by the Legal Services Consumer Panel has found that most individuals prefer flat fees when given the option, ${ }^{73}$ and that overall satisfaction with services is higher among those who paid a fixed fee compared with those who paid an hourly rate. ${ }^{74}$

66 Macfarlane, National Self-Represented Litigants Project, supra note 2 at 121; Birnbaum, Bala \& Bertrand, supra note 34; Paul Vayda, "Chipping away at Cost Barriers: A Comment on the Supreme Court of Canada's Trial Lawyers Decision “ (2015) 36 Windsor Rev Legal \& Soc Issues 207 at 208.

67 Michael McKiernan, “The Going Rate: The 2015 Canadian Lawyer Legal Fees Survey,” Canadian Lawyer (June 2015).

68 Interview with Family lawyer "FF" (female, Toronto, called to the bar 2011), 5 May 2015.

69 Bertrand et al., supra note 47.

70 Michael Carabash, Is Time Running Out on the Billable Hour? (Toronto: Dynamic Lawyers, 2009), online: Dynamic Lawyers < https://www.dynamiclegalforms.com/files/Is_Time_Running_Out_on_the_Billable_Hour.pdf?>; Erik S Knutsen and Janet Walker, "What Is the Cost of Litigating in Canada?" in Christopher Hodges, Stephan Vogenauer \& Magdalena Tulibacka, eds, The Costs and Funding of Civil Litigation: A Comparative Perspective (Portland, OR: Hart, 2010) 239 at s III.A.

71 ACAJCFM, "Colloquium Report" (2014) at 15.

72 Legal Services Consumer Panel (LSCP), Tracker Survey 2015: Data Tables for Recent Users (London: LSCP, 2015).

73 LSCP, “Opening Up Data in Legal Services“ (2016) at 22, online: $<$ http://www.legalservicesconsumerpanel.org.uk/publications/research_and_reports/documents/OpenDatainLegalServicesFinal.pdf $>$.

74 LSCP, Tracker Survey 2013 Briefing Nöte 1: Usage and Funding of Legal Services (London: LSCP, 2013). 
Contingency fees are a more radical option for those family law clients who will eventually receive money from the other side. ${ }^{75}$ Contingency billing in a family law case involves complexities and risks not found in personal injury and class action cases, ${ }^{76}$ and this billing method is currently forbidden by Ontario law for family law cases. ${ }^{77}$ However, contingency has significant affordability benefits. It offers both price certainty (including a no-win-no-fee guarantee that clients value) and the postponement of fee payment until a moment when the client is in a better position to pay it.

\section{Price Structure and Firm Size}

The relatively small size of Canada's family law firms may be an impediment to their adoption of innovative, accessible billing models. This is because models such as flat fees and contingency billing impose increased risks on a firm, compared to hourly billing with a cash retainer. For example, if a matter requires more labour than initially expected, the firm does poorly on a flat fee. If the monetary recovery is unexpectedly low or the necessary labour input is unexpectedly high, the firm will do poorly on a contingency basis. These risks do not seem to make the billing models less profitable in the long run (contingency-billed personal injury and class action practices are among the most lucrative of all legal niches), but they do increase the variability and unpredictability of the firm's revenues.

Larger firms are better able to absorb this variability because they can spread the risk over a larger number of cases. ${ }^{78}$ However, the average Ontario family lawyer in 2014 worked in a firm with only 6.2 lawyers, ${ }^{79}$ and slightly over half (51 percent) of Ontario family lawyers are sole practitioners. By contrast, the average Ontario lawyer in private practice works in a firm of approximately forty lawyers. In the United Kingdom and Australia, firms with hundreds of lawyers are now offering family law services, and, as predicted, these services are often made available on a flat fee basis. ${ }^{80}$ By contrast, in Canada's six largest firms, comprising thousands of lawyers, only four individuals practise family law. ${ }^{81}$ Scaling up a family law firm is difficult in Canada due to the continuing regulatory prohibition of non-lawyer investment. ${ }^{82}$ However, those that can do so may find themselves in a strong position to move away from time-based, cash-retainer billing and thereby serve a large untapped market.

75 That is, those who will receive child and/or spousal support or a sum in respect of family property adjustment.

76 Tali Folkins, “Time for Contingency Fees in Family Law?," Law Times (Ontario) (8 June 2015); Olivia Carville, "Lawyers Fight 'Archaic' Ban on No-Win No-Fee Arrangements in Family Court," Toronto Star (31 May 2015).

77 Solicitors Act, RSO 1990, c S.15, s 28(3)(b).

78 Semple, Legal Services Regulation at the Crossroads, supra note 51 at 164-167.

79 The LSUC data recorded firm size in categories (that is, "6-10 lawyers") as opposed to integers. For the purpose of this calculation, it was assumed that each lawyer's firm size was equal to the average of the upper and lower bounds of the firm size category. For example, all lawyers reported to work in firms of six to ten were presumed to work in firms with eight lawyers. "Family lawyer" is defined here to mean lawyers who did any family law work at all in 2014. Family law specialists (those who allocated at least $60 \%$ of their work hours to family law) had a slightly larger average firm size: 7.5 lawyers.

80 Semple, Legal Services Regulation at the Crossroads, supra note 51 at 167; See note 69 above and accompanying text.

81 Canada's largest law firms were identified using the following source. Lexpert, "Canada's Largest Law Firms," $<$ www.lexpert.ca/500/canadas-largest-law-firms/ $>$. The directories of lawyers on their websites were searched to identify family lawyers.

82 Noel Semple, “Access to Justice: Is Legal Services Regulation Blocking the Path?“ (2013) 21 Intl J Legal Profession 267, online: $<$ http://ssrn.com/abstract=2303987> [Semple, “Access to Justice”]. 


\section{B. Innovation in Service Variety}

Variegation of services is the second type of innovation that family firms can pursue. ${ }^{83}$ The "traditional full-scope retainer" continues to characterize most family law services. ${ }^{84}$ Under this model, the firm takes on full responsibility for solving all legal aspects of the client's problem from beginning to end. ${ }^{85}$ Commensurate with this responsibility, under the traditional full-scope retainer, the firm, rather than the client, makes most of the major decisions about how and by whom the necessary legal tasks will be performed.

\section{Limited Scope Retainers}

One innovative alternative is limited scope (also known as "unbundled") services. ${ }^{86}$ In these models, the firm's responsibility to the client is limited to certain legal issues, to certain stages of the proceeding, or to certain constituent tasks but not others. The most important appeal of limited scope retainers is their affordability: the client pays less because he or she does more of the work personally instead of the firm. A limited scope service such as drafting a pleading is also much easier for a firm to price with a fixed fee because the labour requirements are relatively predictable. A Sarnia family lawyer describes her pragmatic approach to a limited scope retainer in the following way:

The reality is people come in, they've got a problem, and I am trying to figure out how best I can help them. It is great if they can just hire you to do whatever. But the reality is depending on the services and their financial situation, some people can't afford it. So it's always been that figuring out what you can and can't do for people. ${ }^{87}$ In addition to affordability, limited scope retainers offer flexibility and control to those clients who wish to keep more control of their cases. ${ }^{88}$

In personal plight niches like family law, one challenge of limited scope retainers is that the clients are typically legally inexperienced and under financial and emotional stress from the underlying crisis. ${ }^{89}$ Even those who would be capable of handling some parts of their cases alone will have difficulty identifying which parts those might be. ${ }^{90}$ Unlike the general counsel in a large corporate client, they are not usually able to disaggregate their own legal needs and select appropriate portions to allocate to the firm. ${ }^{91}$ Thus, family law firms need to take the lead in designing innovative and affordable ways to divide the workload

83 Semple, Sweet Spot, supra note 11, Chapter 4.

84 Lorne Sossin \& Samreen Beg, "Should Legal Services be Unbundled?" in Noel Semple \& Carol Rogerson, "Access to Family Justice: Insights and Options" in Trebilcock, Duggan \& Sossin, supra note 22, 199.

85 Robert Harvie, "Checking Our Egos and Accepting Our Part Is Fundamental to Restoring Public Trust in the Justice System," National Self-Represented Litigants Project Blog (3 December 2014), online: <

https://representingyourselfcanada.com/checking-our-egos-and-accepting-our-part-is-fundamental-to-restoring-publictrust-in-the-justice-system/ $>$.

86 Sossin \& Beg, supra note 80; ACAJCFM, Meaningful Change for Family Justice, supra note 1; LCO, supra note 3 at 65-66; Robert Harvie, “Self Represented Litigants: Lawyer Delivery Lagging?” Huckvale LLP Blog (20 January 2016), online: <https:/huckvale.ca/family-law/self-represented-litigants-lawyer-delivery-lagging/>.

87 Interview with family lawyer "JJ" (female, Sarnia, called to the bar 1992), 26 May 2015.

88 CBA A2J Committee, supra note 54 at 37.

89 See section I.C.2 above. CBA A2J Committee, supra note 54 at 94 . Regarding lawyers' perception that limited scope retainers increase the risk of client complaints to regulators and malpractice suits, see Harvie, supra note 81.

90 CBA A2J Committee, supra note 54 at 94-95; LCO, supra note 3 at 65-66.

91 Noel Semple, "Personal Plight Legal Services and Tomorrow's Lawyers“" (2014) 2014 Journal of the Legal Profession 25 at 35, online: $<$ ssrn.com/abstract=2436438> [Semple, "Personal Plight Legal Services"]. 
between the firm and the client. "Coaching" is one form of limited scope retainer that has many family law firms have already deployed successfully. In this practice model, the lawyer advises and supports the client for the duration of the matter, but does not represent him or in court or negotiations. ${ }^{92}$

\section{Variegation on Multiple Axes}

In addition to limited scope retainers, there are other forms of service variety that family law firms could offer their clients. In an increasingly multicultural country, offering service in multiple languages is advantageous. Twenty percent of Ontario's family lawyers personally provide services in at least one language other than English. ${ }^{93}$ Further linguistic variety could be offered by firms that hire non-lawyer staff able to do client consultations and translate in other languages, or by firms that use freelance or technologically enabled translation services.

Physical location is another family law service characteristic that firms could variegate to increase accessibility. There is evidence of significant unmet demand in rural areas. ${ }^{94}$ The number of lawyers per capita is typically higher in larger cities, although data from the OCLN project suggests that family lawyers are somewhat more evenly distributed than other types of lawyers are. ${ }^{95}$ In any case, the family law firm that innovatively offers its services in more different places - for example, with consultation offices or a "riding circuit" between communities - will meet more clients' needs.

Even if the family law firm is in town, some clients find traditional offices intimidating. Jane Harvey Lawyers provides family law, among other legal services, from locations in malls in the Toronto area. ${ }^{96}$ This firm offers weekend and evening hours, which is another service option that improves accessibility. Of course, the assumption that a law firm must be physically proximate to its client is increasingly questionable. As Jamie Baxter and Albert Yoon argue in a recent paper, "legal service delivery is not strictly a local phenomenon." 97 Their survey found that in the average Ontario family lawyer's practice, 30 percent of the clients reside more than twenty-five kilometres away from the law office. ${ }^{98}$ Deploying technology such as video conferencing to serve clients in remote communities can create access to justice and attract new clients to a family law firm. ${ }^{99}$

\section{Innovation in Division of Labour}

Division of labour is a third opportunity for family law firms to innovate for accessibility. ${ }^{100}$ Operating a firm requires substantial "non-billable" work that is not connected to a particular file and may not even

92 Nikki Gershbain, Family Legal Services Review Submission on Unbundling \& Legal Coaching (Windsor, Ontario: National Self-Represented Litigants Project, 2017) online: NSRLP <https://representingyourselfcanada.com/wpcontent/uploads/2017/05/Bonkalo-Submission-Coaching-and-Unbundling.pdf $>$ (last accessed: 24 August 2017).

93 Annual Report data provided by LSUC. See note 57 above.

94 CBA Legal Futures Initiative, The Future of Legal Services in Canada: Trends and Issues Report (Ottawa: CBA, 2013) at 16. Sole Practitioner and Small Firm Task Force, LSUC, Final Report (Toronto: LSUC, 2005) at 45-46; Julian Franch, "Small Law Firm Revenue Generation through Strategic Networking in Rural Communities" (2016) at 13-14 [unpublished mauscript, on file with the author].

95 Jamie Baxter \& Albert Yoon, The Geography of Civil Legal Services in Ontario (Toronto: LSUC, 2012 ) at 51.

96 Jane Harvey Lawyers. Axess Law operates in Walmarts, although the firm does not advertise contested family law services. See $<$ http://www.axesslaw.com/services/family $>$.

97 Jamie Baxter \& Albert Yoon, "No Lawyer for a Hundred Miles? Mapping the New Geography of Access of Justice in Canada" (2014) 52 Osgoode Hall LJ 9.

98 Ibid at 38. However, in this survey lawyers in all of the other legal niches had larger proportions of clients more than twenty-five kilometres away.

99 Franch, supra note 89.

100 Semple, Sweet Spot, supra note 11, Chapters 5, 6, 7.. 
be legal in nature. Marketing, bookkeeping, and human resources administration are mundane examples. Passing this work from lawyers into less expensive hands reduces the overall cost of doing business, leading to greater accessibility and profitability. This is hardly news to family lawyers, almost all of who use non-lawyer assistants, clerks, or paralegals to perform some of the necessary work more cheaply than lawyers. However, in niches such as personal injury law, non-lawyers are used much more extensively for client intake and consultation. Doing likewise may be an opportunity for Canadian family law firms.

Sole practitioners have limited opportunities to divide labour unless they send work outside of the firm. If the firm adds more lawyers, then labour can be further divided among them. If a senior lawyer assigns work to a junior, and the junior does it just as effectively for a lower hourly rate, the firm has divided labour and increased efficiency and accessibility. While division of labour is a familiar idea, the principle can be further developed. ${ }^{101}$ Innovating for accessibility requires time for research and development of innovative practice models. Setting flat fees, for example, requires careful analysis of past cases as well as ongoing revision in fee scales. This innovation-oriented research and development work calls for someone who can think systematically about the next 1,000 cases that the firm will handle. A skilled practising lawyer, by contrast, tends to be single-mindedly focused on the one case at hand.

Innovation for accessibility would be facilitated by new faces at the family law firm boardroom table, bringing new capital for expansion and new expertise in fields such as project management, technology, and marketing. ${ }^{102}$ Unfortunately, vestigial business structure rules in North American jurisdictions essentially forbid law firms to bring these new faces to the table as entrepreneurs, investors, or equal partners with lawyers. ${ }^{103}$ However, even if these rules persist, there is still some scope for dividing labour with non-legal experts by employing them or using them as consultants.

The large American consumer law firms of the 1990s (for example, Jaccoby \& Myers and Hyatt Legal Services) retained these human resources at their respective central offices. They leveraged them to make services at their network of hundreds of storefront offices more accessible and profitable. Sociologist Jerry Van Hoy, who was embedded in two of these firms for months, describes the arrangement:

[A]dministrative offices provide a number of services to help ensure the smooth bracket and profitable bracket operation of branch offices. These include advertising, accounting and bookkeeping services, dispersal of funds to pay off ... expenses, help with hiring office staff, providing temporary staff to cover offices during sickness or vacations, negotiating office rental agreements and general advice about the operation of offices and legal matters. ${ }^{104}$

These "franchise" law firms offered affordable fixed fee services in contested family law matters among other personal plight and personal business legal needs - an accessible offering that is very rare in

101 Mitch Kowalski, "De-Constructing Legal Services," Slaw.ca (7 March 2013): "[S]uccessful law firms of the $21^{\text {st }}$ Century will be those who re-jig their staffing models to ensure that work is done by the lowest cost, yet appropriately skilled, provider - or the work is done by technology."

102 Frank Stephen, Lawyers, Markets, and Regulation (Cheltenham, UK: Edward Elgar, 2013), Chapter 8; Gillian K Hadfield, "The Cost of Law: Promoting Access to Justice through the Corporate Practice of Law" (2014) 38 Intl Rev Law \& Economics 43; Gillian Hadfield, "Legal Infrastructure and the New Economy" (2013) 8 I/S: A Journal of Law \& Policy for the Information Society 1; Semple, Legal Services Regulation at the Crossroads, supra note 51 at 175.

103 Semple, "Access to Justice," supra note 79; Gillian Hadfield, Rules for a Flat World: Why Humans Invented Law and How to Reinvent It (New York: Oxford University Press, 2016) at Chapter 9.

104 Jerry Van Hoy, Franchise Law Firms and the Transformation of Personal Legal Services (Westport, CT: Quorum Books, 1997) at 98. 
Canadian family law practice today. ${ }^{105}$ The firms were also innovative in their approach to advertising and locating their practices. Although the Hyatt and Jaccoby firms subsequently (and somewhat mysteriously) moved away from family law, their model shows how division of labour, along with scale, can enable innovation for accessibility in family law practice.

Richard and Daniel Susskind envision an even more radical division of professional labour, one that would spread the work well beyond the walls of the firm. They argue that

professional work should be decomposed, that is, broken down into its constituent 'tasks' - identifiable, distinct, and separable modules of work that make it up. Once decomposed, the challenge then is to identify the most efficient way of executing each type of task, consistent with the quality of work needed, the level of human interaction required, and the ease with which the decomposed tasks can be managed alongside one another and pulled together into one coherent offering. ${ }^{106}$

Once legal work is disaggregated in this way, the Susskinds expect the labour to be divided very broadly - not just within the law firm but also to legal process outsourcers in overseas jurisdictions and, importantly, to increasingly intelligent machines. ${ }^{107}$ This process can improve service quality and reduce the cost of doing business, thereby permitting profitability at more affordable price points. This advanced division of labour by law firms is already lowering costs and increasing efficiency for large corporate clients. ${ }^{108}$ It has not yet extended to family law cases, which are more difficult to disaggregate due to their small size and inexperienced clientele. ${ }^{109}$ Nevertheless, applying advanced "Susskindian" decomposition to family law files is a promising opportunity to innovate for accessibility.

\section{FOR A THIRD REVOLUTION IN CANADIAN FAMILY LAW}

\section{A. The First Revolution: Doctrinal Reform}

Over the past half-century, very important progress has taken place in Canadian family law. A doctrinal revolution began with the 1968 Divorce Act, which, for the first time, made divorce broadly available to those who no longer wished to remain married. ${ }^{110}$ In the 1980 s and 1990 s, the broad contours of Canadian financial family law were established: statutory entitlements to division of matrimonial property, child support, and spousal support. ${ }^{111}$ The creation of the Child Support Guidelines, ${ }^{12}$ and then the Spousal Support Guidelines, ${ }^{113}$ made these areas of the law increasingly clear and non-discretionary. ${ }^{114}$ Over

105 Ibid at 17, 58-59.

106 Richard Susskind \& Daniel Susskind, The Future of the Professions: How Technology Will Transform the Work of Human Experts (New York: Oxford, 2015) at 212. See also Richard E Susskind, Tomorrow's Lawyers: An Introduction to Your Future (Oxford: Oxford University Press, 2013) at ch 4.

107 Susskind \& Susskind, supra note 100 at $121-123$.

108 Ibid at $67 \mathrm{ff}$.

109 Semple, "Personal Plight Legal Services," supra note 87 at 35-36.

110 Divorce Act, SC 1967-68, c 24. The 1985 Divorce Act, supra note 6, extended this liberalization.

111 Carol Rogerson, The Life and Times of the F.L.A. (25th Anniversary of the Family Law Act Conference, Law Society of Upper Canada, Toronto, March 1, 2011) (Toronto: LSUC, 2011) online: <http://ssrn.com/abstract=2182052>.

112 Federal Child Support Guidelines, SOR/97-175 and provincial equivalents.

113 Rogerson \& Thompson, supra note 6. Regarding the significant effect of these Guidelines on settlement and advocacy in family law, see Bertrand et al., supra note 47.

114 Rogerson, supra note 1. 
roughly the same time period, child custody and access law settled upon the best interests of the child standard, which remains its "golden rule." 115

The legalization of same sex marriage in the mid-2000s was arguably the last battle in Canadian family law's doctrinal revolution. Naturally, the law will continue to evolve. However, it seems very unlikely that the next half-century will produce doctrinal changes comparable to those of the past half-century. The powerful feminist and same sex rights movements have essentially accomplished their doctrinal reform goals in family law and now focus their attention elsewhere. Other movements that dispute the doctrinal status quo, such as men's rights groups and social conservatives, seem to lack the power to effect change. ${ }^{116}$

\section{B. The Second Revolution: Alternative Dispute Resolution [ADR]}

Canadian family law has also experienced, and benefited from, an ADR revolution. Mediation of family law cases began in earnest in the early 1980s. It was soon endorsed in the Divorce Act. ${ }^{117}$ Thirty years on, family mediation is a flourishing profession, with its own trade groups, certifications, and extensive scholarship. ${ }^{118}$ Legal aid and justice system administrators now promote and fund mediation as an alternative to litigation, the former being better for the families involved and also (perhaps not coincidentally) cheaper for the taxpayer.

Other ADR options have proliferated. Collaborative family law lets the parties commit mutually to a non-litigated outcome while giving them the benefit of extensive support from lawyers and other professionals. ${ }^{119}$ Mediation-arbitration combines the advantages of mediation with the certainty of arbitration, while keeping separating parties out of court. ${ }^{120}$ Over-reliance on family law ADR has been criticized for disadvantaging domestic violence victims and otherwise vulnerable spouses and for eroding the public benefits of adjudication. ${ }^{121}$ However, this second revolution in Canadian family law has given separating spouses more options than ever before for resolving their disputes without litigation, as well as more state support than ever before for those who choose to use them. ${ }^{122}$ This is a good thing.

\section{The Third Revolution: Innovation for Accessibility}

Thanks to the doctrinal revolution, we have family laws on the books that are generally thought to be fair and just. Thanks to the ADR revolution, we have numerous options for consensual resolution of separation-related disputes. A time-travelling lawyer from 1965 would be astonished, and probably impressed, by how far we have come in these respects. However, the fruits of this progress will remain beyond the reach of many Canadians until the profession foments a third revolution: innovation for accessibility in family law practice. Most separating people will continue to want and need partisan legal professionals to at least advise and often to represent them. Having a legal professional on one's side is a

115 Noel Semple, "Whose Best Interests? Custody and Access Law and Procedure“ (2010) 48 Osgoode Hall LJ 287, online: $<\mathrm{http}: / /$ digitalcommons.osgoode.yorku.ca/ohlj/vol48/iss2/3>.

116 Semple \& Rogerson, supra note 29 at 417.

117 Divorce Act, supra note 6, s 9(2).

118 E.g., Ontario Association of Family Mediators; Family Dispute Resolution Institute of Ontario.

119 Pauline H Tesler, "Collaborative Law: What It Is and Why Lawyers Need to Know About It" (1999) 2008 Am J Family L 215; John-Paul Boyd, "DIT A2J 3: How Small Groups, Acting on Their Own, Can Make Meaningful Change," Slaw.ca (18 March 2016), online: <http://www.slaw.ca/2016/03/18/dit-a2j-3/>.

120 Lorne Wolfson, Family Law Arbitration in Canada (paper presented to the National Family Law Program, 2010).

121 Noel Semple, "Mandatory Family Mediation and the Settlement Mission: A Feminist Critique“" (2012) 24 CJWL 207.

122 Regarding the effect of alternative dispute resolution and other services for separating people on settlement and case outcomes, see Bertrand et al., supra note 47 at 26-27. 
benefit enjoyed by all too few separating people. From society's point of view, partisan family law practice is essential to ease self-representation's severe impact on the courts and to ensure that children and spouses are provided for in the wake of divorce and separation.

That this third revolution has not yet occurred is obvious. Our time traveller from 1965 would be unsurprised by the way family law is generally practised in Canada today: solo practitioners and small firms working from traditional offices during business hours, requiring large cash deposits to work on traditional full scope retainers billed by the hour. These lawyers generally deliver high quality work, and many of them represent legal professionalism at its finest, but they are simply beyond the reach of most people who need them. The Canadian Bar Association's Futures report captures succinctly the relationship between law practice innovation and access to justice. A key indicator of the success of

innovation will be its impact on access to legal services. If more Canadians are able and willing to use lawyers and the justice system for their legal needs, then the legal profession will have responded to the expressed needs of clients and potential clients, who today indicate that legal services are too costly for them to access except in the most dire of circumstances... the profession's duty to act in the public interest requires it to do more in transforming access to legal services. ${ }^{123}$

\section{CONCLUSION}

This article began by arguing that family law is one of this country's worst access-to-justice quagmires. Every year, hundreds of thousands of Canadians find themselves in need of family law's financial, childrelated, and domestic violence-related remedies. ${ }^{124}$ Access to family justice is challenging because, as with other personal plight needs, the needs are novel and unexpected in the person's life, there is an underlying life crisis, and legal fees are hard to afford. However, access to family justice also has unique barriers: there is no pot of gold at the end of the rainbow, there is very limited legal aid, and there is a lack of paralegal service options.

There are three broad areas in which family law firms can innovate to meet these unmet needs and tap this untapped market. Price structure innovation means moving from open-ended time-based billing and large upfront cash retainers towards arrangements that are more affordable for clients (and potentially at least as profitable for firms). Service variety innovation involves not only limited scope retainers but also innovation in service modality and location. Finally, firms can divide the labour involved in family law practice in more innovative ways, through efficient use of non-lawyer support staff and collaborations with non-lawyer talent for managerial improvements and research and development. Firms that scale up will have an advantage in many of these innovation opportunities.

When called to the bar, Ontario lawyers swear that they will "seek to ensure access to justice and access to legal services." "25 Across the country, most lawyers would probably agree with the spirit of this aspiration. This means that, in addition to duties to clients and the courts, lawyers have a collective duty to make their work accessible to the public. Therefore, unless we naively choose to wait for huge infusions of state funding, radical procedural simplification, or the sudden reversion to traditional marriage for life, the time has come to launch Canada's third family law revolution: innovation for accessibility in family law firms.

${ }^{123}$ CBA Legal Futures Initiative, supra note 4 at 32.

124 Farrow et al, supra note 10 at 7; CFCJ, supra note 10 at 2.

125 LSUC, supra note 51 at s $21(1)$. 